This item was submitted to Loughborough's Research Repository by the author.

Items in Figshare are protected by copyright, with all rights reserved, unless otherwise indicated.

\title{
'If a citizen from the homeland runs quicker or jumps higher than foreigners, I feel pleasure. Why, I do not know': The possibilities and limitations of nationalism
}

\section{PLEASE CITE THE PUBLISHED VERSION}

https://doi.org/10.1111/nana.12456

\section{PUBLISHER}

Wiley () The author(s) @ ASEN/John Wiley \& Sons Ltd

\section{VERSION}

AM (Accepted Manuscript)

\section{PUBLISHER STATEMENT}

This is the peer reviewed version of the following article: SKEY, M. 2018. 'If a citizen from the homeland runs quicker or jumps higher than foreigners, I feel pleasure. Why, I do not know': The possibilities and limitations of nationalism. Nations and Nationalism, 24 (4), pp.857-861, which has been published in final form at https://doi.org/10.1111/nana.12456. This article may be used for non-commercial purposes in accordance with Wiley Terms and Conditions for Use of Self-Archived Versions

\section{LICENCE}

CC BY-NC-ND 4.0

\section{REPOSITORY RECORD}

Skey, Michael. 2018. "'if a Citizen from the Homeland Runs Quicker or Jumps Higher Than Foreigners, I Feel Pleasure. Why, I Do Not Know': The Possibilities and Limitations of Nationalism". figshare. https://hdl.handle.net/2134/36468. 
If a citizen from the homeland runs quicker or jumps higher than foreigners, I feel pleasure. Why, I do not know': The possibilities and limitations of nationalism

When a concept has proven so successful and influential over a sustained period of time, it is always good to take stock and see how far the argument has moved on and to what extent subsequent interlocutions have actually sharpened our thinking. In the case of Banal Nationalism, Sophie Duchesne is right to highlight the Anglo-centric bias of much subsequent writing on the topic, call into question the continued failure to critically engage with the 'daily reproduction of the United States' (Billig, 1995: 6) (and one might add the rising super-powers of China and India) and to restate the importance of studying nationalism as an 'international ideology'. However, two of her other claims - concerning the apparent dichotomy between banal and everyday forms of nationalism and, in particular, that subsequent 'everyday' approaches are 'largely devoid of the critical charge originally vehicled (put forward?) by Banal Nationalism' - do deserve further scrutiny.

In the first case, it's always a little surprising to read arguments that set up banal/everyday approaches in opposition to each other or, in Duchesne's case, see one superseding the other. The two approaches are obviously different in terms of emphasis and perspective but ultimately they are designed to complement each other by providing different means of studying the same phenomena (Antonsich, 2016). Banal nationalism was a landmark study designed to draw attention to the ways in which "the assumptions of nationalism, which take for granted the naturalness of a world of nations, have become virtually universal" (Billig, 2009: 349). The other key contribution was that it drew attention to the significance of everyday symbols and language in 'flagging' the nation, thereby shifting attention to how national forms are sustained in the contemporary era. 
Writing in response to criticisms that his approach was somewhat prescriptive and top-down, Billig pointed to his previous work in rhetorical psychology (1996), which emphasised the ways in which people drew on various discursive resources to make sense of, and argue about, the world. As a result, he argued that 'there is nothing in the theoretical background of Banal Nationalism to deny that ordinary people will engage in sense-making' (Billig, 2009: 348) but that nationalism, as a principle for organising political and social relations, has become so naturalised that it often goes unnoticed. This is a helpful clarification and points to the importance of both theorising and studying nationalism as an ideology that is so takenfor-granted that it is often viewed as 'common sense' and the means through which this ideology is materialised, naturalised and, indeed, resisted, primarily by studying a range of everyday practices, signs, institutional arrangements, places and objects.

Moreover, if we acknowledge that Banal Nationalism was informed by a framework that emphasised both argumentation as well as the constraints posed by the "universal frameworks of nationalism" (Billig, 2009: 349), then it is difficult to see how studying "the everyday roles of individuals in the expression and appropriation of national belonging, constitutes a kind of misappropriation" (Duchesne). Likewise, it may well be that metaphorical flags have an important role to play in "legitimising the violence of the international order" (Duschesne) but, ultimately, it is people that carry out and justify such violence and our understanding of nationalism is surely made infinitely poorer but not engaging with individual expressions of national belonging as well as the wider institutional structures that make them hold good.

Elsewhere, the idea that writing on everyday nationhood has obscured Billig's interest in 'the omnipresence of nationalist ideology' (Duschesne) also seems a little overblown. Admittedly, much recent empirical research has focused on studying the particularities of a given national context but arguments about the importance of theorising nationalism as a dominant universal 
framework for making sense of the world are not uncommon either (See, for example, Foster, 2002, Edensor, 2006: 19-20 / 27-30, Skey, 2009: 342-3, 2011: 168-9, 2014: 4, Calhoun, 2017). Similarly, the recently published collection, Everyday Nationhood (so-called not because of any rejection or fear of the tenets of Banal Nationalism but because we couldn't come up with anything better!) features a number of chapters that reiterate this viewpoint when studying, for example, the activities of UNESCO, US foreign policy and austerity debates in the EU. As we write in the conclusion;

Sometimes there has been a tendency in research on the banal features of nationhood to examine them as isolated features of a wider phenomenon without actually paying (enough) attention to the phenomenon itself and how it might be theorised. In other words to move beyond the noting of this or that feature to try and understand how they combine to form more or less embedded frameworks in the lives of substantial numbers (Skey \& Antonsich, 2017: 329)

Perhaps the most troubling claim that Duchesne makes, however, is that "different processes have worked together to translate banal nationalism into everyday nationhood, draining the original thesis of most of it is critical and political content". This is a serious charge but unfortunately it presents both a caricature of the literature on everyday nationhood (as if focusing on people's everyday activities equated to justifying or even celebrating them) and a rather one-dimensional view of what it means to study questions of power in relation to the nation. For while, the macro-perspective of Banal Nationalism, focusing as it does on the state and other powerful institutions matters, so too do the attempts to map the hierarchies of national belonging (Skey, 2013) that inform everyday practices of inclusion and exclusion at the meso and micro-levels of society (For recent empirical examples, see Knott, 2015, Fox \& Mogilnicka, 2017, Pratsinakis, 2017, Wallem, 2017). Moreover, a recent cross-comparative 
analysis of European countries has argued that it is these micro-practices, everyday language, symbols and interactions, that matter far more than any policy framework in shaping feelings of national belonging, notably among minority groups (Bakkaer Simonsen, 2016). Put kindly, it seems like a rather curious oversight to ignore the extent to which micro-level approaches might also offer a complementary critical perspective on these issues.

The question of power, and the hold that national frameworks have on so many lives, leads to a final point. Duchesne's argument is not only that scholars have overlooked nationalism as a powerful ideology but that they have done so for fear of confronting (and perhaps moving beyond) their own attachments to nations. One wonders whether this also applies to Billig who offered a 'confession' about his own feelings of national pride in Banal Nationalism; 'If a citizen from the homeland runs quicker or jumps higher than foreigners, I feel pleasure. Why, I do not know' (1995: 175). Answering that question 'why' should be of fundamental interest to scholars of the nation and everyday approaches are actually much more suited to doing this given their overriding interest in people's lives and experiences. Be that as it may, academics should certainly be willing to acknowledge the manner in which their own lives are - more or less - bound up with the nation, as any form of critical reflection can enable them to better understand why appeals to the nation move and mobilise so many. This doesn't mean condoning actions that exclude, marginalise or brutalise in the name of the nation, far from it. At the same time, to paraphrase Les Back, simply labelling nationalism as bad or wrong doesn't get us very far in theorising its power or the manner in which national frameworks continue to underpin forms of practice, interaction, organisation and sociability that remain valuable for significance numbers around the globe. As Melissa Aronczyk writes; 
This means recognizing that the 'type' of nationalism that allows for expressions of rights and rationales for collective solidarity lies along the same spectrum as its chauvinistic and antagonistic versions. Even as we perceive, through its various manifestations, the possibilities and limitations of nationalism, we may still understand its importance in structuring self-understanding and belonging in the modern world (Aronczyk, forthcoming: xiii)

In the conclusion to his book, Billig suggested that we should 'encourage a habit of watchful suspicion' (1995: 177) in relation to nationalism. Wise words, but such is the complexity of the phenomenon, not to mention the powerful hold it continues to have in defining individuals, their social relations and the wider world we live in, we require as many different perspectives as possible alongside a willingness to acknowledge our own complicity (at least some of the time) in sustaining the idea(l) of nationhood.

\section{Bibliography}

Antonsich, M. (2016). The ‘everyday' of banal nationalism-ordinary people's views on Italy and Italian. Political Geography, 54, 32-42.

Aronczyk, M (forthcoming) Foreword in D, Fehimović and R Ogden (Eds) Branding Latin America, Lanham: Lexington Press

Billig, M. (1996). Arguing and thinking: A rhetorical view of social psychology, Cambridge: Cambridge University Press

Billig, M. (1995). Banal nationalism, London: Sage

Billig, M. (2009). Reflecting on a critical engagement with banal nationalism-reply to Skey. Sociological Review, 57(2), 347-352. 
Calhoun, C. (2017). The Rhetoric of Nationalism. In Everyday Nationhood in Skey, M \& Antonsich, M (Eds) Everyday Nationhood (pp. 17-30). Palgrave Macmillan, London.

Edensor, T. (2002). National identity, popular culture and everyday life. London:

Bloomsbury Publishing.

Foster, R. (2002). Materializing the nation: Commodities, consumption, and media in Papua New Guinea. Indiana University Press.

Fox, J \& Mogilnicka, M, 2017, 'Pathological integration, or, how East Europeans use racism to become British'. British Journal of Sociology.

Knott, E (2015) What Does it Mean to be a Kin Majority? Analyzing Romanian identity in Moldova and Russian Identity in Crimea From Below, Social Science Quarterly, 96(3): 830859

Pratsinakis, M. (2017). Established and outsider nationals: Immigrant-native relations and the everyday politics of national belonging. Ethnicities, 1468796817692838.

Simonsen, K. B. (2016). How the host nation's boundary drawing affects immigrants' belonging. Journal of Ethnic and Migration Studies, 42(7), 1153-1176.

Skey, M (2011) National Belonging \& Everyday Life, Palgrave MacMillan

Skey, M (2014) The mediation of nationhood: Communicating the world as a world of nations, Communication Theory, 24(1): 1-20

Skey, M (2013) Why do nations matter? British Journal of Sociology, 64(1): 81-98

Skey, M \& Antonsich, M (2017) The present and future of nationalism in Everyday Nationhood: Theorising Belonging, Culture \& Identity After Banal Nationalism, Palgrave 
MacMillan

Skey, M \& Antonsich, M (Eds) (2017) Everyday Nationhood: Theorising Belonging, Culture \& Identity After Banal Nationalism, Palgrave MacMillan

Wallem, G. (2017). The Name and The Nation: Banal Nationalism and Name Change Practices in the Context of Co-ethnic Migration to Germany in Skey, M \& Antonsich, M (Eds) Everyday Nationhood (pp. 77-96). Palgrave Macmillan, London. 
